\title{
A Case of Hypothalamic Panhypopituitarism with Empty Sella Syndrome: Case Report and Review of the Literature
}

\author{
HisaKo KOMADA*, MasaAKi YAMAMOTO*, SAKi OKUBO*, KANTO NAGAI*, KeIJ IIDA*, \\ TAKEHIRO NAKAMURA**, YUSHI HIROTA*, KAZUHIKo SAKAGUCHI*, MASATO KASUGA* \\ AND YUTAKA TAKAHASHI* \\ *Division of Diabetes, Metabolism, and Endocrinology, Department of Internal Medicine, Kobe University Graduate school of \\ Medicine, Kobe, Japan \\ **Kobe City Medical Center West Hospital, Kobe, Japan
}

\begin{abstract}
Empty sella syndrome is frequently accompanied with pituitary dysfunction. Most of the patients with empty sella syndrome demonstrate primary pituitary or stalk dysfunction and few cases show hypothalamic dysfunction. A 71year-old man manifested appetite loss, nausea and vomiting with hyponatremia and adrenal insufficiency. Hormonal evaluation and cranial MRI revealed a panhypopituitarism with empty sella. Intriguingly, while the response of ACTH to $\mathrm{CRH}$ administration was exaggerated, the response to insulin hypoglycemia was blunted. Serum PRL levels were normal. Further, decreased level of fT4, slightly elevated basal levels of TSH, and delayed response of TSH to TRH administration were observed. These findings strongly suggest that the panhypopituitarism is caused by hypothalamic dysfunction. The presence of autoantibodies to pituitary and cerebrum in the patient's serum implies an autoimmune mechanism as a pathogenesis.
\end{abstract}

Key words: Empty sella, Hypothalamic, Panhypopituitarism, Adrenal insufficiency, Autoimmune

(Endocrine Journal 56: 585-589, 2009)

EMPTY sella is characterized by the herniation of the subarachnoid space within the sella, which is often associated with some degree of flattening of the pituitary gland [1-2] and first documented by Busch et al. in 1951 [3]. These conditions are classified into two groups, primary or secondary empty sella. In case of primary empty sella, several pathogenesis has been proposed, such as a congenital incomplete formation of the sellar diaphragm and an increase in intracranial pressure. The secondary empty sella is caused by various pathological conditions including pituitary adenomas, injuries, infection, Sheehan's syndrome and

Received Aug. 7, 2008; Accepted Mar. 12, 2009 as K08E-214 Released online in J-STAGE as advance publication Apr. 7, 2009

Correspondence to: Yutaka TAKAHASHI M.D., Ph.D., Division of Diabetes, Metabolism, and Endocrinology, Department of Internal Medicine, Kobe University Graduate school of Medicine 7-5-1, Kusunoki-cho, Chuo-ku, Kobe, 650-0017, Japan.

E-mail: takahash@med.kobe-u.ac.jp lymphocytic hypophysitis [1-2].

It has been reported that empty sella is present in $5.5 \%-23 \%$ of autopsies [3]. In most of the patients, empty sella is found incidentally. It has also been reported that $20-50 \%$ of patients have the endocrinologic dysfunction [4]; partial hypopituitarism has been described in $5 \%$ of patients, total hypopituitarism in $25 \%$ [5] and hyperprolactinemia in 10\% [6]. The most frequent cause of the endocrinological dysfunction is the primary pituitary dysfunction. Several studies have reported primary empty sella in children with hypopituitarism due to the hypothalamic insufficiency [7, 8], however; only one case of empty sella syndrome with hypothalamic hypopituitarism in adulthood has been reported as far as we have searched [9]. Here we present a case of panhypopituitarism with empty sella syndrome in which hypothalamic dysfunction was strongly speculated with a review of the literature. 
Table 1. Laboratory data on admission

\begin{tabular}{|c|c|c|c|}
\hline \multicolumn{2}{|c|}{$<$ Hematology $>$} & \multicolumn{2}{|c|}{$<$ Serological examination $>$} \\
\hline WBC & $10800 / \mu \mathrm{l}$ & CRP & $0.97 \mathrm{mg} / \mathrm{dl}$ \\
\hline $\mathrm{RBC}$ & $328 \times 10^{4} / \mu 1$ & Anti-TPO Ab & $0.3 \mathrm{U} / \mathrm{ml}$ \\
\hline $\mathrm{Hb}$ & $9.8 \mathrm{~g} / \mathrm{dl}$ & Anti-TgAb & $0.9 \mathrm{U} / \mathrm{ml}$ \\
\hline $\mathrm{Ht}$ & $28.4 \%$ & & \\
\hline PLT & $31.9 \times 10^{4} / \mu 1$ & & \\
\hline
\end{tabular}

\begin{tabular}{lrlr}
\hline \multicolumn{2}{l}{$<$ Biochemistry $>$} & \multicolumn{2}{l}{$<$ Hormonal examination $>$} \\
\hline T-bil & $0.5 \mathrm{mg} / \mathrm{dl}$ & GH & $<0.15 \mathrm{ng} / \mathrm{ml}$ \\
AST & $26 \mathrm{IU} / \mathrm{l}$ & IGF-1 & $40 \mathrm{ng} / \mathrm{ml}$ \\
ALT & $21 \mathrm{IU} / 1$ & PRL & $9.0 \mathrm{ng} / \mathrm{ml}$ \\
$\mathrm{LDH}$ & $156 \mathrm{IU} / 1$ & TSH & $1.864 \mu \mathrm{U} / \mathrm{ml}$ \\
$\mathrm{CK}$ & $103 \mathrm{IU} / \mathrm{l}$ & FT4 & $0.71 \mathrm{ng} / \mathrm{dl}$ \\
$\mathrm{TP}$ & $7.7 \mathrm{~g} / \mathrm{dl}$ & LH & $0.3 \mathrm{mIU} / \mathrm{ml}$ \\
$\mathrm{Alb}$ & $4.4 \mathrm{~g} / \mathrm{dl}$ & FSH & $3.0 \mathrm{mIU} / \mathrm{ml}$ \\
$\mathrm{Cr}$ & $0.96 \mathrm{mg} / \mathrm{dl}$ & ACTH & $8.1 \mathrm{pg} / \mathrm{ml}$ \\
$\mathrm{BUN}$ & $21 \mathrm{mg} / \mathrm{dl}$ & Cortisol & $2.2 \mu \mathrm{g} / \mathrm{dl}$ \\
$\mathrm{Na}$ & $129 \mathrm{mEq} / \mathrm{l}$ & PAC & $114 \mathrm{pg} / \mathrm{ml}$ \\
$\mathrm{K}$ & $4.2 \mathrm{mEq} / \mathrm{l}$ & PRA & $0.3 \mathrm{ng} / \mathrm{ml} / \mathrm{hr}$ \\
$\mathrm{Cl}$ & $94 \mathrm{mEq} / 1$ & ADH & $1.14 \mathrm{pg} / \mathrm{ml}$ \\
FPG & $81 \mathrm{mg} / \mathrm{dl}$ & U-17-OHCS & $2.8 \mathrm{mg} / \mathrm{day}$ \\
$\mathrm{HbAlc}$ & $5.7 \%$ & U-17-KS & $3.4 \mathrm{mg} / \mathrm{day}$ \\
P-Osm & $266 \mathrm{mOsm} / \mathrm{kg}$ & U-free cortisol & $<10.5 \mu \mathrm{g} / \mathrm{day}$ \\
\hline
\end{tabular}

\section{Materials and Methods}

Detection for anti-pituitary antibody was performed in two methods. One was a commercially available immunofluorescence using rat pituitary (SRL). The other was immunoblotting analysis using mouse tissues. Immunoblotting analysis was performed as pre-

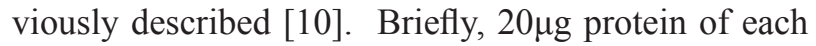
tissue from mice was applied for SDS page. The patient's or control serum was used for primary antibody in 1:500 dilutions. HRP-conjugated goat Anti-Human IgG (Zymed) was used for secondary antibody. Antibody binding was detected using an enhanced chemiluminescence kit (Amersham).

\section{Case report}

A 71-year-old man, $162.7 \mathrm{~cm}$ in height and $63.4 \mathrm{~kg}$ in weight, was admitted to a hospital because of appetite loss, nausea and vomiting. The patient had lost approximately $5 \mathrm{~kg}$ in weight over 3 months. He had
Table 2. Endocrinological examinations

\begin{tabular}{lccccc} 
A) CRH/GHRH/TRH/LHRH test & & & \\
\hline Time $(\mathrm{min})$ & 0 & 30 & 60 & 90 & 120 \\
\hline ACTH $(\mathrm{pg} / \mathrm{ml})$ & 8.4 & 96.8 & 97.7 & 72.4 & 90 \\
Cortisol $(\mu \mathrm{g} / \mathrm{dl})$ & 1.2 & 2.3 & 3.2 & 3.3 & 3.2 \\
TSH $(\mu \mathrm{IU} / \mathrm{ml})$ & 1.937 & 4.587 & 6.56 & 6.886 & 7.007 \\
PRL $(\mathrm{ng} / \mathrm{ml})$ & 8.3 & 12.5 & 12.1 & 11 & 10.6 \\
GH $(\mathrm{ng} / \mathrm{ml})$ & $<0.15$ & 1.43 & 2.24 & 1.57 & 1.02 \\
LH $(\mathrm{mIU} / \mathrm{ml})$ & 0.2 & 0.9 & 1.2 & 1.3 & 1.3 \\
FSH $(\mathrm{mIU} / \mathrm{ml})$ & 3.1 & 3.7 & 4.1 & 4.2 & 4.4
\end{tabular}

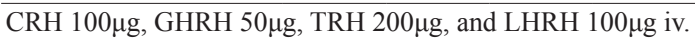

B) Insulin tolerance test

\begin{tabular}{lccccc}
\hline Time $(\mathrm{min})$ & 0 & 30 & 60 & 90 & 120 \\
\hline Glucose $(\mathrm{mg} / \mathrm{dl})$ & 83 & 33 & 54 & 68 & 77 \\
GH $(\mathrm{ng} / \mathrm{ml})$ & $<0.15$ & $<0.15$ & 0.15 & $<0.15$ & $<0.15$ \\
ACTH $(\mathrm{pg} / \mathrm{ml})$ & 0.5 & 0.4 & 0.9 & 0.9 & 0.9 \\
Cortisol $(\mu \mathrm{g} / \mathrm{dl})$ & 9.6 & 9.7 & 13.4 & 10.7 & 10.3 \\
\hline
\end{tabular}

insulin $0.05 \mathrm{U} / \mathrm{kg} \mathrm{BW}$ iv.

\section{C) GHRP-2 test}

\begin{tabular}{lccccc}
\hline Time $(\mathrm{min})$ & 0 & 15 & 30 & 45 & 60 \\
\hline GH $(\mathrm{ng} / \mathrm{ml})$ & $<0.15$ & 0.78 & 1.12 & 1.01 & 0.71 \\
\hline GHRP-2 $100 \mu \mathrm{g}$ iv. & & & & &
\end{tabular}

D) $\mathbf{5 \%}$ hypertonic saline test

\begin{tabular}{lccccc}
\hline Time $(\mathrm{min})$ & 0 & 30 & 60 & 90 & 120 \\
\hline P-Osm $(\mathrm{mOsm} / \mathrm{kg})$ & 266 & 269 & 272 & 275 & 277 \\
U-Osm $(\mathrm{nOsm} / \mathrm{kg})$ & 379 & 359 & 308 & 292 & 304 \\
$\mathrm{Na}(\mathrm{mEq} / \mathrm{l})$ & 128 & 132 & 132 & 135 & 137 \\
$\mathrm{ADH}(\mathrm{pg} / \mathrm{ml})$ & 0.5 & 0.65 & 0.6 & 0.88 & 0.87 \\
\hline
\end{tabular}

a history of herpes encephalitis when he was 60 -yearold. Routine laboratory tests showed a marked hyponatremia (112mEq/1 (normal range, $135-149 \mathrm{mEq} /$ 1)). Hormonal evaluation revealed decreased level of cortisol $(<1.0 \mu \mathrm{g} / \mathrm{dl}$ (normal range, $2.7-15.5 \mu \mathrm{g} /$ $\mathrm{dl})$ ), low normal level of ACTH $(11 \mathrm{pg} / \mathrm{ml}(9-52 \mathrm{pg} /$ $\mathrm{ml})$ ), decreased level of free T4 $(0.54 \mathrm{ng} / \mathrm{dl}(0.7-1.7 \mathrm{ng} /$ dl)) and slightly elevated level of TSH $(7.78 \mu \mathrm{IU} / \mathrm{ml}$ $(0.05-5.00 \mu \mathrm{IU} / \mathrm{ml}))$. The patient was given a diagnosis of panhypopituitarism and treated with hydrocortisone replacement followed by levothyroxine sodium replacement. After the treatment, the patient's symptoms rapidly improved. For further evaluation, the patient was referred to our hospital. On the admission day, routine laboratory tests showed hyponatremia $(129 \mathrm{mEq} / \mathrm{l})$, decreased serum osmolarity and mild anemia. Hormonal evaluation under levothyroxine replacement showed decreased cortisol, ACTH, fT4 and IGF-I levels. The basal levels of TSH and PRL were in the normal range. Urine 17-OHCS, KS and free cortisol excretion were decreased (Table 1). The basal ACTH concentrations ranged from 0.5-8.4 pg/ml, 

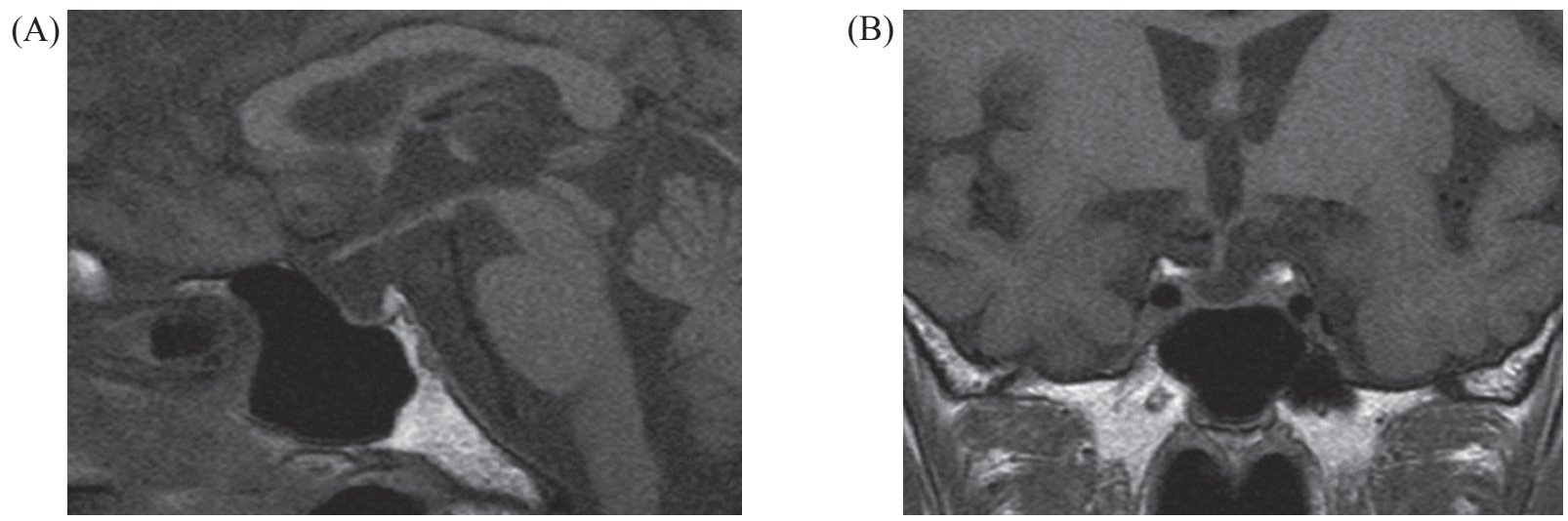

Fig. 1. MR image of the pituitary. Sagittal and (B) coronal T1-weighted MR image demonstrate a presence of empty sella.

and peak concentrations after insulin-induced hypoglycemia and CRH administration were 0.9 and 97.7, respectively (Table 2). The response of TSH to TRH administration was normal but delayed. The basal GH concentrations were $<0.15 \mathrm{ng} / \mathrm{ml}$, and peak concentrations after insulin-induced hypoglycemia and GHRP-2 administration were 0.15 and 1.12 , respectively. A pituitary magnetic resonance imaging (MRI) demonstrated empty sella (Fig 1). In T1WI image, high signal intensity of the posterior pituitary was detected. He showed polyuria (more than $4000 \mathrm{ml} /$ day) at the admission to our hospital. His urine and plasma osmolality were $588 \mathrm{mOsm} / \mathrm{kg}$ and $266 \mathrm{mOsm} / \mathrm{kg}$, respectively. In the $5 \%$ hypertonic saline test, plasma sodium concentration maintained low $(128 \sim 137 \mathrm{mEq} /$ 1). Although, his urine osmolality was higher than that in plasma, the degree of urinary concentration was not enough and plasma ADH levels kept in low levels (Table 2). These data suggest a presence of partial central diabetes insipidus. In serological analysis, both of anti-TPO and -Tg antibodies were positive. We speculated autoimmune mechanisms for the pathogenesis. Then we explored a presence of pituitary antibody in the patient's serum. Although serum antipituitary antibody using immunofluorescence was not detected, Western blotting analysis showed that the patient's serum specifically recognized several proteins in mouse pituitary and cerebrum (Fig 2).

\section{Discussion}

We present a case of empty sella with panhypopituitarism. Interestingly, while the response of ACTH to
$\mathrm{CRH}$ administration was exaggerated, the response to insulin hypoglycemia was blunted. These results indicate a presence of hypothalamic or pituitary stalk dysfunction. Generally, hyperprolactinemia is frequently observed in empty sella syndrome with stalk dysfunction [6]. In this case, the normal basal level of PRL and normal response of PRL to TRH administration suggest that stalk function is intact. Further, low concentration of fT4 and slightly elevated levels of TSH, and delayed response of TSH to TRH administration suggest hypothalamic dysfunction or TRH deficiency [11-13]. In addition, polyuria and limited elevation of urinary osmolality during hypersaline test suggest a presence of partial central diabetes insipidus. Taken together, it is strongly suggested that the panhypopituitarism is caused by hypothalamic dysfunction.

Although, several studies have reported hypothalamic insufficiency with empty sella in children [7, 14], it is extremely rare in adulthood [9]. In children, congenital deficiency or structural anomaly in the hypothalamus has been suggested as a cause $[15,16]$. However, the cause of hypothalamic dysfunction with empty sella syndrome in adulthood has been totally unknown. In the previous report, autoimmune thyroiditis was accompanied with hypothalamic dysfunction with empty sella syndrome [9]. In the present case, anti-TPO and -Tg antibodies were detected in the serum as well. Both of the hypothalamic and pituitary dysfunction were observed in a case of Sheehan's syndrome [17], suggesting that ischemic changes in pituitary and hypothalamus could also cause these conditions. Further, in the present case, he has a history of herpes encephalitis at 59 years old, so that it can not be ruled out that this inflammatory disease caused 

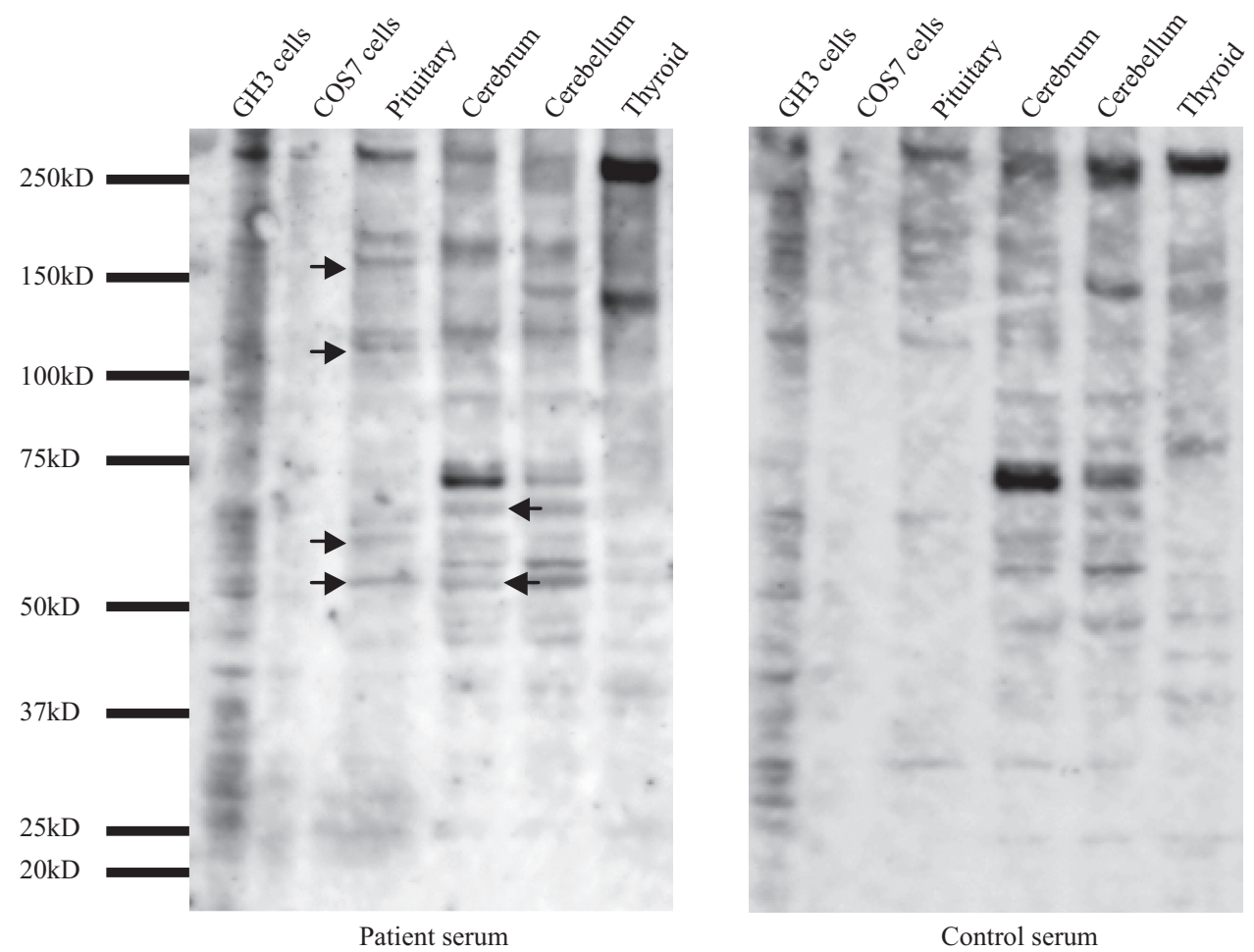

Fig. 2. The patient's serum specifically recognized several proteins in mouse pituitary and cerebrum. Arrows indicate auto-antigens in these tissues.

hypothalamic damage, however, it is unlikely based on the time course. The onset of adrenal insufficiency and the enhanced response of ACTH to CRH administration indicate that the hypothalamic dysfunction has occurred recently.

In the aspect of pathogenesis, autoimmune thyroid disease is frequently observed in the patients with lymphocytic hypophysitis. $75 \%$ of cases with lymphocytic hypophysitis demonstrate chronic autoimmune thyroiditis (Hashimoto's thyroiditis) $[18,19]$. Intriguingly, autoantibodies that recognize antigens in mouse pituitary and cerebrum were detected in the patient's serum by immunobloting analysis. These data suggest that autoimmune mechanisms were involved in the impairment both of hypothalamus and pituitary. In lymphocytic hypophysitis, it is reported that the secretion of plasma ACTH is the most frequently im- paired [20]. However, in our case, ACTH secretion to $\mathrm{CRH}$ administration was reserved. These features suggest a presence of atypical cause distinct from common hypophisitis.

In summary, we present a case of panhypopituitarism with empty sella syndrome in adulthood. Endocrinological findings strongly suggest hypothalamic dysfunction as a cause of panhypopituitarism. Autoimmune mechanisms were suggested as a pathogenesis.

\section{Acknowledgements}

We thank Drs. T Nishiumi and A Murawaki for fruitful discussion on the case.

\section{References}

1. Bergland RM, Ray BS, Torack RM (1968) Anatomical Variations in the pituitary gland and adjacent structures in 225 human autopsy cases. J Neurosurg 28:93-99.
2. McLachlan MS, Williams ED, Fortt RW, Doyle FH (1968) Estimation of pituitary gland dimensions from radiographs of the sella turcica. A post-mortem study. 
Br J Radiol 41:323-330.

3. Busch W (1951) Morphology of sella turcica and its relation to the pituitary gland. Virchows Arch 320:437458

4. Kaufman B, Chamberlin WB Jr (1972) The Ubiquitous 'Empty' sella turcica. Acta Radiol Diagn (Stockh) 13:413-425.

5. Arai H (2006) Empty sella syndrome. Nippon Rinsho. Review: 212-216.

6. De Marinis L, Bonadonna S, Bianchi A, Maria G, Giustina A (2005) Primary empty sella. J Clin Endocrinol Metab 90:5471-5477.

7. Soliman AT, Darwish A, Asfour MG (1995) Empty sella in short children with and without hypothalamicpituitary abnormalities. Indian J Pediatr 62:597-603.

8. Shulman DI, Martinez CR, Bercu BB, Root AW (1986) Hypothalamic-pituitary dysfunction in primary empty sella syndrome in childhood. J Pediatr 108:540-544

9. Kikuchi Y, Yamakawa T, Okamura A (2006) A case of hypothalamic adrenal insufficiency with Hashimoto's thyroiditis and empty sella. Nippon Naibunpitu Gakkai Zasshi (Endocrine Journal) 82:177 (Abstract) (In Japanese)

10. Takahashi Y, Shirono H, Arisaka O, Takahashi K, Yagi T, Koga J, Kaji H, Okimura Y, Abe H, Tanaka T, Chihara (1997) Biologically inactive growth hormone caused by an amino acid substitution. K.J Clin Invest 100:1159-1165

11. Samuels MH, Ridgway EC (1992) Central hypothyroidism. Endocrinol Metab Clin North Am 21:903-919

12. Winter WH, Signorino MR (2001) Review: molecular thyroidology. Ann Clin Lab Sci 31:221-244

13. Yamada M, Saga Y, Shibusawa N, Hirato J, Murakami M, Iwasaki T, Hashimoto K, Satoh T, Wakabayashi K, Taketo MM, Mori M (1997) Tertiary hypothyroidism and hyperglycemia in mice with targeted disruption of the thyrotropin-releasing hormone gene. Proc Natl Acad Sci U S A 94:10862-10867

14. Shulman DI, Martinez CR, Bercu BB, Root AW (1986) Hypothalamic-pituitary dysfunction in primary empty sella syndrome in childhood. J Pediatr 108:540-544

15. Zucchini S, Ambrosetto P, Carla G, Tani G, Franzoni E, Cacciari E (1995) Primary empty sella: differences and similarities between children and adults. Acta Paediatr 84:1382-1385

16. Baş F, Darendeliler F, Yapici Z, Gökalp S, Bundak R, Saka N, Günöz H (2006) Worster-Drought syndrome. $J$ Pediatr Endocrinol Metab 19:535-540

17. Onose H, Tamura Y, Fujita H, Nanano T, Shibasaki T (2003) A case of Sheehan's syndrome with Panhypopituitarism due to the impairment of both the hypothalamus and the pituitary. Endocr J 50:415-419.

18. Hashimoto K, Takao T, Makino S (1997) Lymphocytic adenohypophysitis and infundibuloneurohypophysitis. Endocr J 44:1-10.

19. Juan-Andres Rivera (2006) Lymphocytic hypophysitis: Disease spectrum and approach to diagnosis and therapy. Pituitary 9:35-45

20. Hashimoto K, Asaba K, Tamura K, Takao T, Nakamura $\mathrm{T}$ (2002) A case of lymphocytic infundibuloneurohypophysitis associated with systemic lupus erythematosus. Endocr J 49:605-610. 